\title{
【奨励賞研究】
}

\section{一般化線形モデルを用いた上肢運動機能リハビリ における戦略変化予測モデル}

\author{
石浦 直樹 \\ 東京理科大学 基礎工学研究科 電子応用工学専攻
}

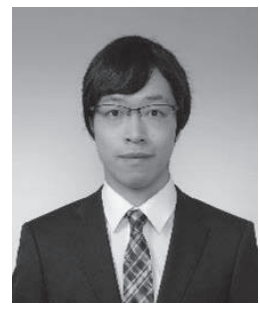

\section{1. 背景}

脳性小肾麻痺(CP:Cerebral Palsy)は, 生後早期における脳の中枢 神経系に損傷を受けることで発症する神経障害である. 近年の臨床 実験において, “やる気や頑張り”を司る脳の側坐核の働きを活性化 することで, 脳神経障害からの効果的な運動機能回復が期待できる といら報告がなされた. 従って, 子供にとってやる気を引き出すリ八ビ リ環境の構築が求められる一方で, やる気の傾向変化などを客観的 に評価可能なモデルの構築なども重要な課題となってくる.

\section{2. システム概要}

我々は, $\mathrm{CP}$ 患者の運動機能改善を目的とした VR リハビリシステ ム:VCT(Virtual Catching Task) (Fig.1)を開発してきた. 1)VCT とは, 仮 想空間内に被検者の上半身の動きを投射したアバタを通し，画面上 のさまざまな角度から飛来するバーチャルオブジェクに店するこ とが求められるタスクである.

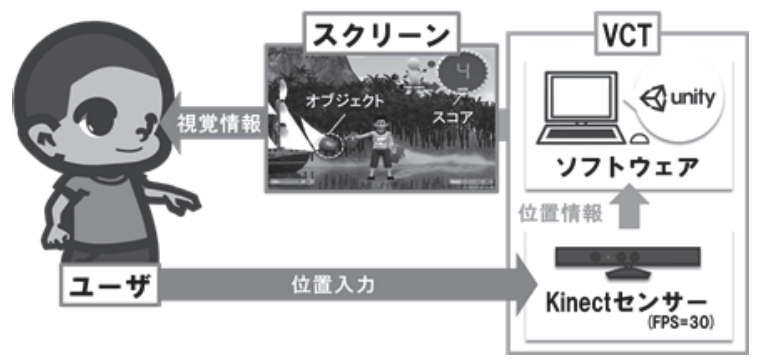

Fig.1 VCT のシステム構成

\section{3. 目的}

先行研究において, CP 患者 3 名(7.0 2.08 歳)を対象として, 計 10 日間に及び同様のタスク水準の VCT を行わせる実験を行い, 得 られた腕の角度情報の解析を行った. 結果, タスクスコアの上昇に伴 い, オブジェクトに反応後の腕の待機角度がタスク開始日と比較し有 意に変化(p<.001)してい<傾向が確認できた(戦略変化). 本研究で は, VCT 中の腕の待機角度変化について一般化線形モデル (GLM) を用いてモデル化し, 戦略変化の予測を行う。

\section{4. 戦略変化予測モデル}

先行研究において得られた各患者の腕の角度情報を用いて, オブ ジェクト反応後の腕の待機角度を von Mises 分布(式(1))を用いて統 計モデル化した.ここで, $\mu$ は分布の平均方向, $\kappa$ は集中度を表す。

$$
f(\theta \mid \mu, \kappa)=\frac{\exp \{\kappa \cos (\theta-\mu)\}}{2 \pi I_{0}(\kappa)}, I_{0}(\kappa)=\sum_{i=0}^{\infty} \frac{\left(\frac{\kappa^{2}}{4}\right)^{i}}{i ! \Gamma(\mathrm{i}+1)}
$$

$\mathrm{CP}$ 患者の 1 日目及び 10 日目における待機角度の von Mises 分布 近似を比較した結果, 両分布について有意に変化していることを確 認した $(\mathrm{p}=0.0013(<.005))$.この結果を用いて, 10 日目の平均方向 $\mu_{10 d a y}$ ヘシフトする過程をモデル化するため, 待機角度が $\mu_{10 d a y}$ に 置かれる頻度を 20 トライアルごとにカウントし, そのカウント值がポア ソン分布に従うと仮定した. 平均值入を応答変数とし, 日数 $x_{1: d a y}$, 夕 スクスコア $x_{2: s c o r e}$, そして von Mises 分布のパラメータ推定值(平均 方向 $x_{3: \mu}$, 集中度 $x_{4: \kappa}$ を説明変数として, GLM によるモデルを構築 した(式(2), $\mathrm{AIC}=25.8423)$.ここで, $\alpha$ 及び $\beta_{1 \sim 4}$ は定数である.

$$
\log \left(\lambda_{i}\right)=\alpha+\beta_{1} x_{1: \text { day }, i}+\beta_{2} x_{2: s c o r e, i}+\beta_{3} x_{3: \mu, i}+\beta_{4} x_{4: K, i}
$$

作成したモデルについて, テストデータを当てはめた際の実測值と 予測值との比較を行った(Fig.2, RMSE=1.1277).

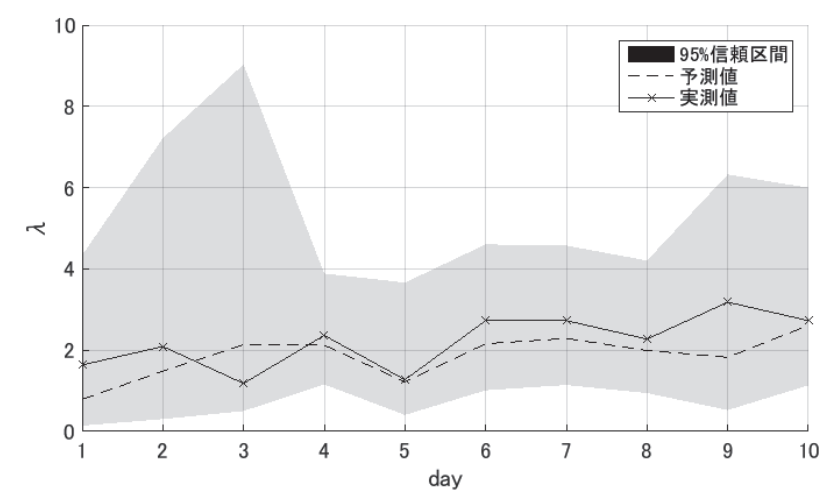

Fig.2 予測值及び実測值

\section{5. 結論}

リハビリが順調に進むにつれ，患者自身が感じるタスクの困難度は 低くなる. そして, 反応すべきオブジェクトに対する警戒度は低下(馿 化)し, 患者の振る舞いに変化が起きる. 今回, その振る舞いの変化 の特徵が腕の待機角度といら部分に見られ，その変化を戦略変化と してモデル化することが出来た. 作成したモデルから得られる予測 值を基に戦略変化の変化点を検出することで, 動的なタスク困難度 調整モデルへの応用にも繋がる.

\section{参考文献}

1) Yamaguchi $T$, Ishiura $N$, Richard P, et al., "Analysis of arm movement strategy in virtual catching task", 10th Intl Conf. on Disability, Virtual Reality and Assoc. Technologies, pp. 89-97, 2014. 